\title{
DEVELOPMENT OF AN INTEGRATED FRAMEWORK FOR ASSESSING AND IMPROVING THE PERFORMANCE OF MANUFACTURING INDUSTRIES IN DEVELOPING COUNTRIES
}

\section{OPRACOWANIE ZINTEGROWANYCH SCHEMATÓW RAMOWYCH DO OCENY I POPRAWY WYDAJNOŚCI PRODUKCYJNYCH BRANŻ PRZEMYSLOWYCH W KRAJACH ROZWIJAJĄCYCH SIĘ}

\author{
Chanan S. Syan, Krystal Ramoutar
}

Department of Mechanical and Manufacturing Engineering The University of the West Indies St. Augustine, Trinidad, West Indies. Email: chanan.syan@sta.uwi.edu

\begin{abstract}
In developing countries, there is an overwhelming challenge to diversify the economy from the primary sectors to more value adding and income generating sustainable secondary or manufacturing sectors. As global competitiveness intensifies, it is imperative that manufacturing organizations in developing countries can compete at a global level. This research focuses on Trinidad and Tobago (T\&T) and the wider Caribbean region. However, its applicability and relevance is extensive. This paper investigates the manufacturing techniques/practices currently implemented in T\&T with focus on companies that are compliant with quality and health and safety policies. This study advocates the need for a strategic approach for the successful implementation of worldclass manufacturing (WCM) techniques/practices in T\&T manufacturing industry. The methodology as well as research instruments developed and used are presented.
\end{abstract}

Keywords: Manufacturing Performance, World-class Manufacturing, Trinidad and Tobago, Health and Safety, ISO 9000.

Streszczenie: W krajach rozwijających się istnieje wszechobecne dążenie do dywersyfikacji gospodarki i przejścia od pierwotnych gałęzi w kierunku branż pozwalających uzyskać większą wartość dodaną i generujących wyższe zyski, należących do sektorów zrównoważonych, zaawansowanych technologicznie lub przetwórczych. Ponieważ globalna konkurencja jest coraz bardziej intensywna, oczywistym imperatywem jest fakt, iż organizacje produkcyjne w krajach rozwijających się mogą konkurować na poziomie globalnym. Niniejsze badania skupiaja się na Trynidadzie i Tobago (T\&T) i w szerszym pojęciu - rejonie Karaibów, jednak zakres ich zastosowania oraz przydatność sa o wiele szersze. Niniejszy artykuł omawia badania dotyczace technik i praktyk wytwarzania stosowanych obecnie w Trynidadzie i Tobago, skupiając się na firmach, które działają zgodnie z zasadami polityki jakości oraz zdrowia i bezpieczeństwa (BHP). To badanie popiera potrzebę opracowania strategicznego podejścia $\mathrm{W}$ celu pomyślnego wdrożenia światowej klasy technik i praktyk wytwarzania (WCM) w przemyśle Trynidadu i Tobago. Przedstawiona jest metodologia badań, a także opracowane i stosowane narzędzia badawcze.

Słowa kluczowe: wydajność wytwarzania, światowej klasy techniki wytwarzania, Trynidad i Tobago, Zdrowie i Bezpieczeństwo (BHP), ISO 9000. 


\section{Introduction}

In this rapidly changing international economic environment, small economies such as the islands of the Caribbean are quite uncertain about the chances of progress, and even survival. While the Caribbean is actively attempting to strengthen the region through integration with the establishment of the CARICOM Single Market and Economy (CSME) as a means of survival (Girvan, 2007), a similar process is taking place at the global level. Caribbean countries must contemplate fundamental economic restructuring that would allow them to be internationally competitive.

In this context, the government of T\&T needs to diversify the economy to ensure sustainable development. T\&T economy is bi-polar and that is based on essentially the energy and the non-energy sectors. Continuous expansion in the energy sector makes it the major contributor to the country's economy. In 2006, the economy was approximately 60 per cent dependent on the revenues from oil and gas for economic growth and development (Central Bank of Trinidad and Tobago, 2006). Therefore, diversification is being focused on the non-energy sector as stated in the government's 2008 Budget Presentation (Trinidad and Tobago, 2008) as one of its main priority "to accelerate efforts to diversify the economy by stimulating investment in the non-energy sectors."

Historically, manufacturing was an insignificant sector in T\&T economy, dwarfed by agriculture and oil. In the 1970s to 1980 s, there was a phase of rapid economic development when petroleum prices rose. The Government of T\&T attempted to spread the benefits of the increase in petroleum prices. Imports were even restricted in an effort to encourage local manufacturing (West, 2001). Although the manufacturing sector remained relatively small in the 1980s, it spanned a wide range of activities from sugar processing to automobile assembly. By the late 1980 s, growth in the manufacturing sector was experienced due to the inclusion of petrochemical and steel production (Meditz and Hannatty, 1989). Since then, the sector has continuously expanded its role in the economy of T\&T. Currently, the manufacturing sector in T\&T is divided into the following sections: (a) Food, Drink and Tobacco; (b) Textiles, garments, footwear and headwear; (c) Printing, publishing and paper converters; (d) Wood and related products; (e) Chemicals and non metallic minerals; (f) Assembly type and related Industries; and (g) Miscellaneous manufacturing. Output in the non-energy sector experienced a growth rate of 6.5 per cent in 2006, a somewhat lower growth rate when compared to a rate of 8.7 per cent in 2005 . A strong growth of 11.8 percent was recorded in manufacturing as a result of increased output in the Food, Beverages and Tobacco and the Assembly-Type industries. This was the second highest growth experienced in the non-energy sector, with construction and quarrying being the highest (14.5 per cent) (Central Bank of Trinidad and Tobago, 2006). 
Opracowanie zintegrowanych schematów ramowych do oceny...

Thus, further development of the manufacturing sector has prospective in sustaining the economy in the long term.

The increased international competition for manufactured products has led to the worldwide adoption of quality systems standards and particularly the ISO 9000 series. The legislative parameters within which manufacturing organizations operate have changed due to the recent enactment of the Trinidad and Tobago Occupational, Safety and Health (OSH) Act (OSH Act, 2004). ISO 9001:2002 requires that the organization provide and maintain the infrastructure and work environment needed to enhance the performance of the organization which includes safety guideline, ergonomics, workplace location, hygiene, cleanliness, noise, vibration and pollution (ISO 9001: 2002). The health and safety aspect of organizations have gain tremendous attention and quite necessary for organizations in developing countries to attain world-class status.

Review of recent studies found that there was an absence of research contributing to the assessment of manufacturing performance and identification of areas for improvement in the manufacturing industry of T\&T, even companies that are ISO 9000 certified. Only a few studies on WCM implementation in developing countries were discovered (Salaheldin 2005; Salaheldin and Eid 2007; Saxena and Sahay 2000). Thus, this research, in the context of T\&T, is novel yet practical and fulfils the identified, urgent need for manufacturing companies, even in $T \& T$, to attain WCM status in order to remain competitive.

The purpose of this research study is to emphasize the need to investigate the manufacturing techniques/practices currently implemented and assess the factors influencing the implementation of WCM techniques/practices in manufacturing organizations in T\&T. Focus will be placed on organizations that have become ISO 9000 certified.

The paper is organized into two main sections as follows. First, a comprehensive literature review is conducted about the evolution of manufacturing performance, and diagnoses what is the current view on how to improve manufacturing performance in organizations. The relationship between improving manufacturing performance and WCM implementation was established. The importance of assessing the actual implementation phase was discussed. A comparison of methods for successful implementation of WCM was then reported. Secondly, the research instruments developed to obtain the relevant information is discussed. This paper shows the usefulness of the research instruments developed in identifying the issues and gaps in successfully implementing WCM techniques/practices in T\&T. 


\section{Development of Grounded Theory}

\subsection{Manufacturing Performance}

It is well documented that companies must effectively deploy their business objectives down through the organization and subsequently measure their performance as a key element in order to achieve a sustainable competitive advantage (De Toni and Tonchia 1996; Ghalayini et al. 1997; Kennerley and Neely 2002; Pun and White 2005). However, the subject of how organizations should assess their performance has been a challenge. Gomes et al. (2004) systematically examined the literature dealing with the different facets of manufacturing performance measurement and proposed a conceptual framework highlighting the evolution of manufacturing performance measures and measurement. The author attempted to refine the two-phase of evolution proposed by Ghalayini and Noble (1996). Thus, literature has concluded that the future of performance measurement systems must be viewed as a collection of procedures, techniques, processes as well as people working together toward continuously improving the multi-facets of manufacturing performance and measurement. The increasing importance of continuous improvement has led many researchers to support this view (Barnes et al. 1998; Neely et al. 2000; Garengo et al. 2005). ISO 9001: 2002 defines continual improvement as the recurring activities to increase an organization's overall performance and it should be a permanent objective of the organization.

\subsection{WCM Relationship with Improving Manufacturing Performance}

According to Schonberger (1986), WCM means continual and rapid improvement in all areas of the company. Voss (1995) states that "the continuous improvement of best practice in all areas of the organisation will lead to superior performance capability leading to increased competitiveness." There is no universally recognised definition of WCM (Kodali et al. 2004). The term was first introduced by Hayes and Wheelwright (1984) to describe organizations which achieved a global competitive advantage through use of their manufacturing capabilities as a strategic weapon. However, Greene (1991) gave an in-depth definition and it states that WCM companies are 'companies which continuously outperform the industry's global best practices and which know intimately their customers and suppliers, know their competitors' performance capabilities and know their own strengths and weaknesses. All of which form a basis of - continually changing competitive strategies and performance objectives.'

Since the term 'world-class' was introduced by Hayes and Wheelwright (1984), many researchers have expanded on the concept. Schonberger (1987) even used WCM to refer to many techniques and technologies designed to enable a company to match its best competitors. These techniques include just in time (JIT), material requirements planning (MRP), flexible manufacturing system (FMS), computer 
Opracowanie zintegrowanych schematów ramowych do oceny...

aided design (CAD), computer aided manufacturing (CAM), total quality management (TQM) and supply chain management just to name a few.

The field is rather scattered with many articles focusing on one or a limited set of new practices, while the reasons why these practices are considered best are often not accounted for. There are many companies that do not reach world-class status, due to the definition of best practices in these studies. Thus, the definition of WCM is imperative when conducting studies. For the purposes of this research paper, world-class manufacturing in the studies analysed will include any of the techniques referred to by Schonberger (1987). It is important to note that WCM in these studies would include only a few of these techniques but never the entire domain of WCM.

WCM practices are also considered generic. The potential influence of factors like type of industry, company size, processes and products is not considered. Pursuit of world-class status in a global market means constant change. World-class status or best practices are relative terms, rather than an absolute standard. In other words, concepts, strategies and technologies are constantly being improved upon. Thus, what is considered to be the best or 'world-class' also continuously changes. There is no single limit to world-class status. However, global competitiveness requires that world-class status be an always elusive goal.

\subsection{WCM Implementation}

In the WCM implementation field, the tendency has been to focus on specific improvement techniques such as those mentioned by Schonberger (1987). Studies conducted with best manufacturing practices such as total quality management (TQM), just-in-time (JIT), total preventative maintenance (TPM) and benchmarking confirm that, upon successful implementation, these best practices lead to an improvement in performance (Laugen 2005). However, there is an absence of practical and detailed guidelines specifically for the implementation of WCM practices to achieve excellence within manufacturing.

Saraph (1989) developed a model which suggests how organizational context are related to perceived ideal and actual WCM practices. The basic concept of this framework is to decipher the difference between the actual level of WCM implementation and the ideal level of WCM implementation. If these discrepancies were significant the organization should respond to correct them. This model can assess the status of WCM in an organization in order to direct improvements or assess the status of an organization with relation to others in the same industry.

Gilgeous and Gilgeous (1999) proposed a generic process that manufacturing organizations can follow in order to become world-class status. A framework is also developed that shows how initiatives and their enablers combine to directly link the strategic level of the organizations down to those activities at the operating level of the organization. If these eight initiatives were successfully implemented in 
an organization, that organization would progress towards manufacturing excellence of world-class status.

However, many researchers believe that the actual process of implementation is critical to the successful improvement of organizations performance and requires more focus. Hackman and Wageman (1995) and Wang and Ahmed (2001) concluded that, when implemented well, world-class manufacturing practices such as TQM can help organizations improve their performance.

Thus, investigating the critical factors that are driving and inhibiting the implementation WCM techniques is recommended so that principle strategies and actions can be undertaken to remove any severe obstacle before the actual implementation.

\subsection{ISO 9000 Review}

Introduced in 1987, ISO 9000 is a set of five universal standards for a quality assurance system that has been adopted around the world. Since its publication, ISO 9000 has been perceived and adopted as an important initial stage in a manufacturing organizations' development towards 'total quality' and the benefits of achieving ISO 9000 certification have been well documented (Quazi and Pradibjo, 1998). Many researchers have concluded that companies often use ISO 9000 as a route to world class status (Prabhu et al. 2000 and Najmi and Kehoe, 2000). Previous research identified that only a relatively small proportion of companies go beyond the requirements of the standard (Mann and Kehoe, 1994). Ho (1995) stated, "the ISO 9000 series should be regarded as the beginning of a continuous improvement rather than the end."

In T\&T, an Occupational Health and Safety Bill has been introduced on several occasions. The first draft of this bill was introduced to the House of Representatives in 1975. But the successful passage of the Occupational Safety and Health (OSH) Act No. 1 of 2004 on January 30 and the Amendments in 2006 can be identified as perhaps the most important development in health and safety in this country. This is the first major revision of this legislation since the 1940s. The Act represents a holistic development of the Factories Ordinance (1948) and "Employment of Women (Night Work) Act". These two legislations represent guidelines that companies locally, follow in terms of health and safety. The Factories Ordinance, for instance, showed specific requirements for promoting health and safety of workers in factories. At the core of the Occupational Safety and Health Act, are the OSH Act's "General Duty" and "Specific Duty Clauses." The general duty clause requires employers to furnish their employees with a working environment free from recognized hazards. The specific duty clause requires employers to comply with workplace safety and health standards. Violation of either clause may lead to civil or criminal sanctions against the employer. In general, the objective of the Act is to promote and secure the safety 
Opracowanie zintegrowanych schematów ramowych do oceny...

and health of persons at work. It paved the way for the establishment of an OSH Authority as the regulatory body directly accountable for occupational safety and health in Trinidad and Tobago. This body will provide leadership and control in the execution and implementation of the National OSH Policy.

A requirement of being ISO 9000 certified is that management should define, provide and maintain the infrastructure necessary to achieve its goals while considering the needs and expectations of interested parties. The plan for the infrastructure should consider the identification and mitigation of associated risks and should include strategies to protect the interests of interested parties. According to ISO 9004:2002, management should ensure that the work environment has a positive influence on motivation, satisfaction and performance of people in order to enhance the performance of the organization. Creation of a suitable work environment, as a combination of human and physical factors, should include consideration of safety rules and guidelines, ergonomics, workplace location, heat, humidity, light, airflow, hygiene, cleanliness, noise, vibration and pollution. Companies that are ISO 9000 certified will have an intensified health and safety programme ensuring all of the above. An organization adherence to health and safety and its environment is imperative in attaining a world-class status.

Based on the findings of the literature research conducted, it is proposed that focus should be placed on investigating the drivers and more importantly the barriers to successful WCM implementation in the context of T\&T manufacturing industry that are ISO 9000 certified. This should be conducted before the actual implementation phase. If barriers exist, strategies or action plans focused on that particular factor should be formulated and executed. Another critical factor assessment should take place to determine if significant barriers to WCM implementation are still present. In other word, it is proposed that the barriers to WCM implementation should be deciphered and eliminated before the actual implementation of WCM technique occurs. This ensures that the organization is well equipped in all aspects to handle the implementation phase.

\section{Research Methodology}

Comprehensive literature review has identified the main elements of the research and the need to successfully implement WCM techniques/practices in manufacturing organizations in T\&T to sustain a competitive advantage. 
The general concepts of this study are depicted in the diagram below (Figure 1).

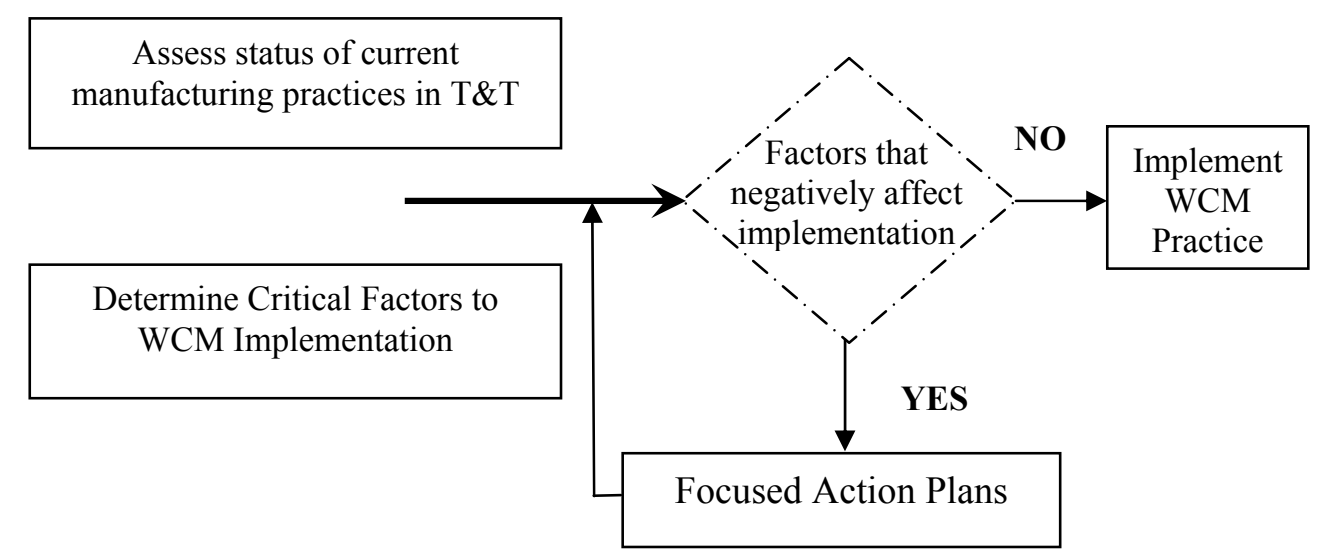

Fig. 1 General Methodology of Research Study

For this form of research, the means of collecting and assessing the information obtained was two-fold (as depicted in Figure 1): (1) questionnaire survey and (2) case studies/ interviews.

\subsection{Development of Research Instruments}

\section{Survey Design}

In order to implement WCM techniques/practices or improve manufacturing performance, assessment of the current state of operations at the manufacturing facilities in T\&T must be conducted first and foremost. To evaluate the current manufacturing practices, an industrial survey was developed suitable for T\&T manufacturing industry. This instrument has been developed using wide ranging research from developing countries including Egypt and India (Salaheldin and Eid, 2007; Digalwar and Sangwan, 2007). The variables are literature based, however, based on input from the pilot test conducted, the appropriateness of the variables and their classification under each measure (construct) was verified. The questionnaire is addressed to the Production/Operations Manager or an equivalent position in the manufacturing corporation. This position was identified as the most appropriate person to answer the questionnaire. Respondents were asked to rate each variable under a five-point interval rating scale to indicate the extent of practice within their respective organization. This approach is consistent with the method adopted by Saraph et al (1989) in their study on critical factors of quality management. 
Development of an integrated framework for assessing....

Opracowanie zintegrowanych schematów ramowych do oceny...

\section{Case Studies / Interview Design}

To ensure successful implementation of WCM techniques/practices, the factors that influence the adoption of these practices in a T\&T context needs to be explored. Based on the literature review, a list of drivers and barriers to successful WCM implementation was developed. The main drivers identified were divided into external and internal drivers (Table 1).

Table 1: Drivers to WCM Implementation

\begin{tabular}{|c|c|c|c|c|c|c|c|c|}
\hline DRIVERS & 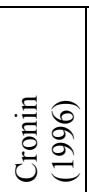 & 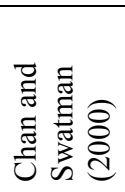 & 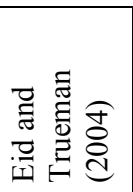 & 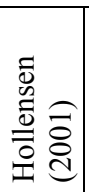 & 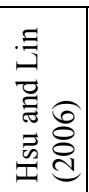 & 咅 & 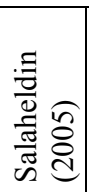 & 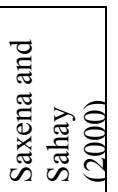 \\
\hline \multicolumn{9}{|c|}{ EXTERNAL DRIVERS } \\
\hline $\begin{array}{l}\text { Global } \\
\text { Competition }\end{array}$ & $\checkmark$ & & & $\checkmark$ & $\checkmark$ & & $\checkmark$ & $\checkmark$ \\
\hline $\begin{array}{l}\text { Change in } \\
\text { International } \\
\text { Customers' } \\
\text { Needs }\end{array}$ & & & $\checkmark$ & $\checkmark$ & $\checkmark$ & $\checkmark$ & $\checkmark$ & $\checkmark$ \\
\hline $\begin{array}{l}\text { Development } \\
\text { s in } \\
\text { Information } \\
\text { Technology }\end{array}$ & $\checkmark$ & $\checkmark$ & $\checkmark$ & & & $\checkmark$ & & \\
\hline \multicolumn{9}{|c|}{ INTERNAL DRIVERS } \\
\hline $\begin{array}{l}\text { Changes in } \\
\text { Organizationa } \\
1 \text { Strategies }\end{array}$ & $\checkmark$ & $\checkmark$ & & & & $\checkmark$ & & \\
\hline $\begin{array}{l}\text { Reduced } \\
\text { Operating } \\
\text { Costs }\end{array}$ & & & & & & $\checkmark$ & & \\
\hline
\end{tabular}

Some internal motivations are to improve the organizations efficiency by reducing waste, reducing operating costs, improving the quality of products, improving profitability. Some external drivers are to maintain a competitive edge, to satisfy customers and pressures from the external environment. The common barriers to WCM implementation are presented in Table 2.

Detailed case studies incorporating structured interviews are developed to investigate the drivers and barriers to successful WCM implementation in T\&T. This phase is an Analytical Hierarchy Process (AHP) based study which is essential since AHP can accommodate both objective and subjective judgments of the evaluators involved in order to make a trade-off and to determine priorities. Thus, the questions were based on pair-wise comparisons, applicable to the AHP framework. For the purposes of this phase of data collection, the interviewee is the same person who had answered the questionnaire previously. Prior to the interview, he/she is provided with the structured interview questionnaire. 
Table 2: Barriers for WCM Implementation

\begin{tabular}{|c|c|c|c|c|c|c|c|c|c|c|c|c|}
\hline BARRIERS & 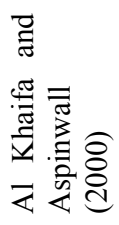 & 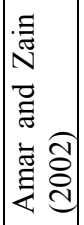 & 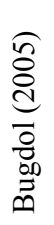 & 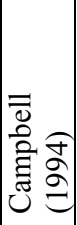 & 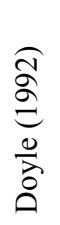 & 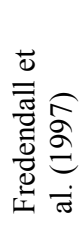 & 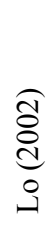 & 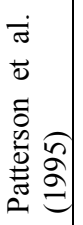 & 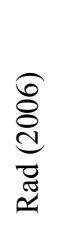 & 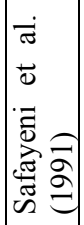 & 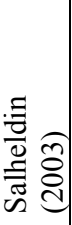 & 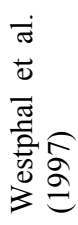 \\
\hline $\begin{array}{l}\text { Lack of } \\
\text { Manageme } \\
\text { nt Support }\end{array}$ & $\checkmark$ & $\checkmark$ & $\checkmark$ & & $\checkmark$ & $\checkmark$ & $\checkmark$ & & $\checkmark$ & $\checkmark$ & $\checkmark$ & \\
\hline $\begin{array}{l}\text { Inadequate } \\
\text { Planning }\end{array}$ & $\checkmark$ & $\sqrt{ }$ & $\sqrt{ }$ & & & & $\checkmark$ & $\sqrt{ }$ & $\checkmark$ & & & $\checkmark$ \\
\hline $\begin{array}{l}\text { Lack of } \\
\text { Knowledge }\end{array}$ & & $\sqrt{ }$ & & & $\checkmark$ & & & $\sqrt{ }$ & & $\sqrt{ }$ & $\sqrt{ }$ & \\
\hline $\begin{array}{l}\text { Lack of } \\
\text { Employee } \\
\text { Education } \\
\text { and } \\
\text { Training } \\
\end{array}$ & & $\checkmark$ & & $\checkmark$ & & $\checkmark$ & $\checkmark$ & $\checkmark$ & $\checkmark$ & & $\checkmark$ & \\
\hline $\begin{array}{l}\text { Resistance } \\
\text { to Change }\end{array}$ & $\checkmark$ & $\checkmark$ & & $\checkmark$ & & & $\checkmark$ & $\checkmark$ & & & $\checkmark$ & $\checkmark$ \\
\hline $\begin{array}{l}\text { Lack of } \\
\text { Employee } \\
\text { Motivation }\end{array}$ & $\checkmark$ & & $\checkmark$ & & & $\checkmark$ & & & $\checkmark$ & & & \\
\hline $\begin{array}{l}\text { Lack of } \\
\text { Communi } \\
\text { cation }\end{array}$ & & $\checkmark$ & & & & $\checkmark$ & $\checkmark$ & & & & & $\checkmark$ \\
\hline
\end{tabular}

Figure 2 below describes the data collection methodology adopted and how the research instruments are used in conducting the research.

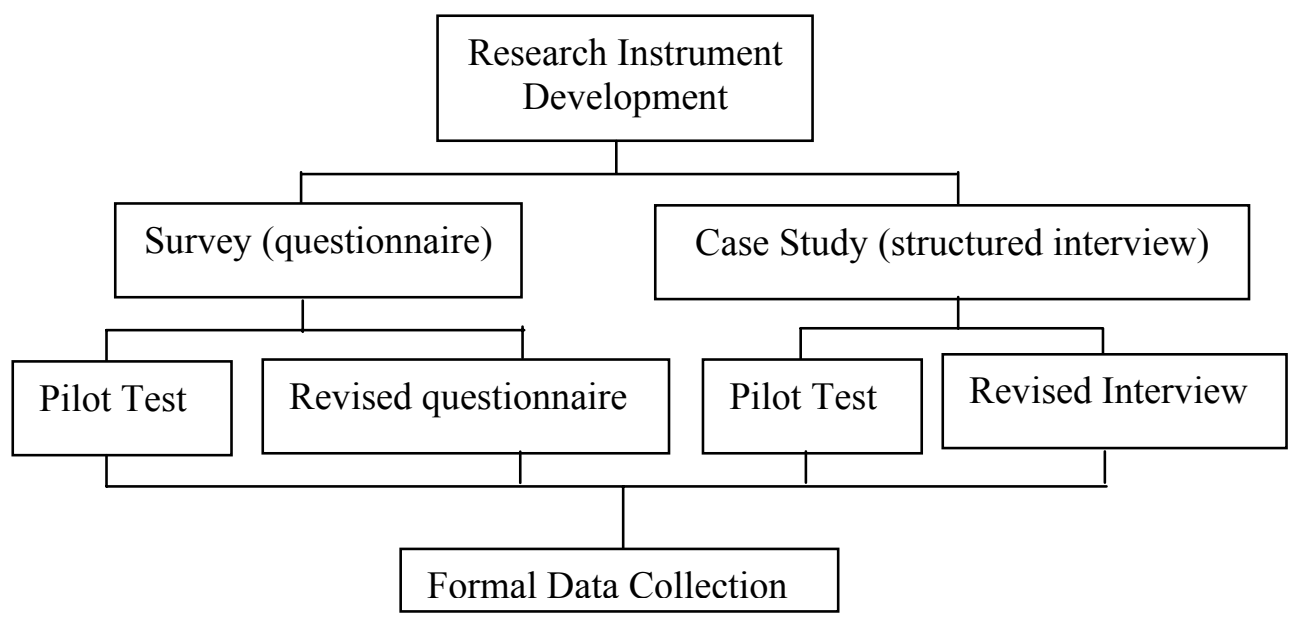

Fig. 2 An overview of the Research Instruments Methodology 
Development of an integrated framework for assessing....

Opracowanie zintegrowanych schematów ramowych do oceny...

\subsection{Pilot Studies}

The two rigorous instruments to analyze the status of T\&T manufacturing organizations and factors which may influence the adoption of WCM techniques/practices in T\&T was developed at the university. The targeted manufacturing organizations were identified from the membership listing of the Trinidad and Tobago Manufacturers' Association (TTMA) and the Trinidad and Tobago Bureau of Standards (TTBS). However, the survey and case studies are focused on companies that are ISO 9000 certified. Thus, the data collection is geared towards ISO 9000 certified manufacturing companies in T\&T.

Pretesting of the research instruments was conducted by eliciting reviews from academic researchers experienced in this area of study and conducting a pilot test with a small sample of firms. The pilot test takes the form of an interview whereby the participants is handed a copy of the questionnaires and asked to complete it followed by a discussion on any comments or questions they may have. Based on the outcome of the pre-testing process, the questionnaires were revised prior to conducting the formal survey.

\section{Research Progress to Date}

The research instruments were designed as stated above and the pilot studies were completed. The research instruments developed is applicable to manufacturing industries in any part of the world. However, the data collected is from T\&T manufacturing industries so the analysis will be in the context of T\&T. The instruments developed were modified based on suggestions from the pilot studies and the formal survey will be carried out. Various statistical approaches are conducted with the data collected from the survey using a computing package called SPSS (originally, Statistical Package for the Social Science). This software can be used to analyze reliability and validity of the data. Expert Choice software will be used to analyze the data collected from the AHP-based case studies.

Future research work includes completing the formal survey, validating and modifying the models and providing viable strategies to improving WCM implementation in the Caribbean Region. Research work will also be conducted in close collaboration with Egyptian and Indian manufacturing sectors and will involve comparative analysis of developing countries in various parts of the world.

\section{Conclusion}

In today's complex and rapidly changing business environment, the importance of evaluating and improving the performance of manufacturing organizations was emphasized in order to remain competitive. This study also emphasizes the need 
for an organisation to establish the foundations for achieving and sustaining continuous improvement. WCM techniques and practices are identified as competent in improving an organization's performance and sustaining continuous improvement. This paper identified how critical successful implementation of world-class manufacturing techniques/practices is in order to improve organizational performance.

The research instruments developed in this paper, to assess the manufacturing techniques/practices implemented in $\mathrm{T} \& \mathrm{~T}$ and the factors influencing the successful adoption of WCM implementation, is used to acquire empirical evidence to support and fill the gap in this research area. Empirical evidence was gathered from ISO 9000 certified manufacturing organizations since health and safety within the work environment would have been a major priority of these companies. An organization's adherence to health and safety and its environment was identified as being imperative in attaining a world-class status.

It is anticipated that this study would significantly contribute to this under researched area, specifically in T\&T. As previously mentioned, there has not been any reported research on the assessment of the techniques/practices implemented to measure manufacturing performance and identification of areas for improvement in $\mathrm{T} \& \mathrm{~T}$. Thus, this research represents an important step towards creating awareness among manufacturing organizations work force, consultants in this field and government officials about the strategic importance of evaluating manufacturing performance in T\&T. The following are expected to be the end-result of this research project:-

- An insight into the manufacturing performance strategies currently being adopted in T\&T

- A strategic approach to improve manufacturing performance in T\&T

The availability of such information will be used to conduct more in-depth studies aimed at implementing viable strategies to improve manufacturing performance, thus diversifying the nation's economy through the development of the Manufacturing Industry in T\&T. A very significant contribution of further research in this area is to provide guideline/approach to improve manufacturing performance in T\&T, which can be utilized as a template by others.

This research study may provide some insight for other research to be conducted in the field of improving manufacturing performance in other Caribbean countries and developing countries in the world. 
Development of an integrated framework for assessing....

Opracowanie zintegrowanych schematów ramowych do oceny...

\section{References}

1. Al Khalifa, K.N. and E. M. Aspinwall.: The development tof TQM in Qatar. The TQM Magazine, v. 12, no 3. p. 194 - 204, 2000.

2. Amar, K. and Z. M. Zain.: Barriers to implementing TQM in Indonesian manufacturing organizations. The TQM Magazine, v. 14, no 6, p. $367-372$, 2002.

3. Barnes, M., T. Dickinson, L. Coulton, S. Dransfield, J. Field, N. Fisher, I Saunders and D Shaw.: A new approach to performance measurement for small to medium enterprises. Proceedings of the Performance Measurement Theory and Practice Conference, Cambridge, 14 - 17 July 1998.

4. Bugdol, M.: The implementation of TQM philosophy in Poland. The TQM Magazine, v. 17, no 2, p. 113 - 120, 2005.

5. Campbell, J. L.: Recent trends in institutional analysis: bringing culture back into political economy. Working Paper, Harvard University, Boston, MA, 1994.

6. Central Bank of Trinidad and Tobago, Ministry of Finance: Annual Economic Survey 2006, Review of the National Economy, Trinidad, 2006.

7. Chan, C. and P. M. C. Swatman.: From EDI to internet commerce: the BHL steel experiences. Internet Research: Electronic Networking Applications and Policy, v. 10, no 1, p. $72-82,2000$.

8. Cronin, M. J.: The Internet Strategy Handbook: Lessons from the New Frontier of Business, Harvard Business School Press, Boston, MA, 1996.

9. Digalwar, A. K. And K. S. Sangwan.: Development and validation of performance measures for world-class manufacturing practise in India. Journal of Advanced Manufacturing Systems, v. 6, no 1, p. 21 - 38, 2007.

10. De Toni, A. and S. Tonchia.: Lean organisation, management-by-process and performance measurement. International Journal of Operations and Production Management, v. 16, no 2, p. 221 -236, 1996.

11. Doyle, K.: Who's killing total quality? Incentive, v. 16, no 8, p. 12 - 19, 1992.

12. Eid, R. and M. Trueman.: Factors affecting the success of business-to-business international internet marketing (B-to-B IIM): an empirical study of UK companies. Industrial Management and Data Systems, v. 104, no 1, p. $16-30$, 2004.

13. Fredendall, L. D., J. W. Patterson, W. J. Kennedy and T. Griffin.: Maintenance: modeling its strategic impact. Journal of Managerial Issues, v. 9, no 4, p. $440-453,1997$.

14. Garengo, P., S. Biazzo and U. S. Bititci.: Performance measurement systems in SMEs: A review for a research agenda. International Journal of Management Reviews, v. 7, no 1, p. 25 - 47, 2005.

15. Ghalayini, A. M. and J. S. Noble.: The changing basis of performance measurement. International Journal of Operations and Production Management, v. 16, no 8, p. $63-80,1996$. 
16. Ghalayini, A. M., J. S. Noble and T. Crowed.: An integrated dynamic performance measurement system for improving manufacturing competitiveness. International Journal of Production Economics, v. 48, no 3, p. $207-225,1997$.

17. Gilgeous, V. and M. Gilgeous.: A framework for manufacturing excellence. Integrated Manufacturing Systems, v. 10, no 1, p. 33 - 44, 1999.

18. Girvan, N: Towards a Single Development Vision and the Role of the Single Economy, CARICOM Secretariat, Guyana, 2007.

19. Gomes, C.F., M. M. Yasin, and J. V. Lisboa.: A literature review of manufacturing performance measures and measurement in an organizational context: a framework and direction for future research. Journal of Manufacturing Technology Management, v. 15, no 6, p. 511 - 530, 2004.

20. Greene, A.: Plant-wide systems: a world class perspective. Production Inventory Management, v. 11, no 7, p. 14 - 15, 1999.

21. Hackman, J.R. and Wageman.: Total quality management: empirical, conceptual and practical issues. Administrative Science Quarterly, v 40, p. 309 $-342,1995$.

22. Harriss, J.: 'Japanization': context and culture in the Indonesian automotive industry. World Development, v. 23, no 1, p. 117 - 128, 1995.

23. Hayes, R.H. and S.C. Wheelwright.: Restoring our Competitive Edge: Competing through Manufacturing, John Wiley, New York, 1984.

24. Ho, S.K.M.: Is the ISO 9000 series for total quality management. International Journal of Physical Distribution \& Logistics Management, v. 25, no 1, p. 51 66, 1995.

25. Hollensen, S.: Global Marketing: A Market-Responsive Approach, $2^{\text {nd }}$ Ed. Pearson Education Limited, Harlow, 2001.

26. Hsu, L. L. and T. M. Lin.: The longitudinal literature review on the interaction between manufacturing and marketing: a multi-dimensional content analysis. International Journal of Management and Enterprise Development, v. 3, no 1, p. $114-146,2006$.

27. International Organization for Standardization (ISO), 2002: Quality management systems - guidelines for performance improvements. ISO 9004.

28. International Organization for Standardization (ISO), 2002: Quality management systems - requirements. ISO 9001.

29. Kennerley, M. and A. Neely.: A framework of the factors affecting the evolution of performance measurement systems. International Journal of Operations and Production Management, v. 22, no 11, p. 1222 - 1245, 2002.

30. Kodali, R. B., K. S. Sangwan and V. K. Sunnapwar.: Performance value analysis for the justification of world-class manufacturing systems. Journal of Advanced Manufacturing Systems, v. 3, no 1, p. 85 - 102, 2004.

31. Laugen, B. T. N. Acur, H. Boer and J. Frick.: Best manufacturing practices What do the best-performance companies do? International Journal of Operations and Production Management, v. 25, no 2, p. 131 - 150, 2005. 
Development of an integrated framework for assessing....

Opracowanie zintegrowanych schematów ramowych do oceny...

32. Lo, T. Y.: Quality culture: a product of motivation within organization. Managerial Auditing Journal, v. 17, no 5, p. 272 - 276, 2002.

33. Mann, R.S. and D.F. Kehoe.: An evaluation of the effects of quality improvement activities on business performance. International Journal of Quality and Reliability Management, v. 11, no 4, p. 29 - 40, 1994.

34. Meditz, S. W. and D. M. Hannatty. Islands of the Commonwealth Caribbean: A Regional Study, Library of Congress, Washington D.C, 1989.

35. Najmi, M. and D.F. Kehoe.: An integrated framework for post-ISO 9000 quality development. International Journal of Quality and Reliability Management, v. 17, no 3, p. 226 - 258, 2000.

36. Neely, A., J. Mills, H. Richards, M. Gregory, J. Bourne and M. Kennerley.: Performance measurement system design: developing and testing a processbased approach. International Journal of Operations and Production Management, v. 20, no 10, p. $1119-1145,2000$.

37. Patterson, J. W., W. L. Kennedy and L. D. Fredendall.: Total productive maintenance is not for this company. Production and Inventory Management Journal, v. 36, no 2, p. $61-64,1995$.

38. Prabhu, V., A. Appleby, D. Yarrow and E. Mitchell.: The impact of ISO 9000 and TQM on best practice/performance. The TQM Magazine, v. 12, no 2, p. 84 $-91,2000$.

39. Pun, K.F. and A.S. White.: A performance measurement paradigm for integrating strategy formulation: A review of systems and frameworks. International Journal of Management Reviews, v. 7, no 1, p. 49 - 71, 2005.

40. Quazi, H. A. and S. R. Padibjo.: A journey towards total quality management through ISO 9000 certification - a study on small and medium-sized enterprises in Singapore. International Journal of Quality and Reliability Management, v. 15, no 5, p. 489 - 508, 1998.

41. Rad, A. M. M.: The impact of organizational culture on the successful implementation of TQM. The TQM Magazine, v. 18, no 6, p. 606-625, 2006.

42. Safayeni, F., L. Purdy, R. van Engelen and S. Pal.: Difficulties of just-in-time implementation: a classification scheme. International Journal of Operations and Production Management, v. 11, no7, p. 27 - 36, 1991.

43. Salaheldin, I. S. JIT implementation in Egyptian manufacturing firms: some empirical evidence. International Journal of Operations and Production Management, v. 25, no 4, p. $354-370,2005$.

44. Salaheldin, I. S. and R. Eid. The implementation of world class manufacturing techniques in Egyptian manufacturing firms. Industrial Management and Data Systems, v. 107, no 4, p. $51-566,2007$.

45. Saraph. J., P. Benson and R. Schroeder. An Instrument for Measuring the Critical Factors of Quality Management. Decision Sciences, v. 20, no 4, p. 812, 1989.

46. Saxena, K. and B. Sahay.: Managing IT for world-class manufacturing: the Indian scenario. International Journal of Information Management, v. 20, no. 1 , p. $29-57,2000$. 
47. Schonberger, R.J.: World Class Manufacturing: The Lessons of Simplicity Applied, The Free Press, New York, 1986.

48. Schonberger, R. J.: World Class Manufacturing: Implementing JIT and TQC, The free Press, New York, 1987.

49. Skinner, S.: Business-to-Business E-Commerce: Investment Perspective, Durlacher Ltd, London, 1999.

50. Trinidad and Tobago, Ministry of Finance: Office of the Prime Minister: Budget Statement 2008, Trinidad, 2008.

51. Voss, C.A.: Alternative paradigms for manufacturing strategy. International Journal of Operations and Production Management, v. 15, no 4, p. 5 - 16, 1995.

52. Wang, C. L. and P. K. Ahmed.: Energising the organization - A New agenda for business excellence. Measuring Business Excellence, v. 5, no 4, p. 22 - 27, 2001.

53. West, Jacqueline. South America, Central America and the Caribbean 2002. 10 ed. Taylor \& Francis Group, London, 2001.

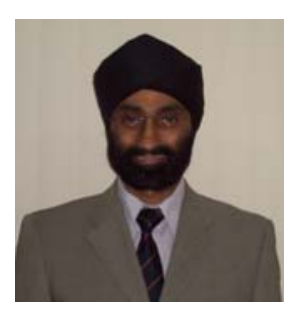

Professor Chanan S Syan graduated from the University of Bradford, UK in 1983 with a BEng (Hons) in Mechanical Engineering. In 1988 he obtained a doctorate from the University of Hull, UK. He has over 10 years of industrial experience and over 20 years in academia at all levels. Presently, he is head of Production Engineering and Management, Leader of Graduate programmes and Professor at the University of the West Indies. Specialisations include - Brain Computer Interface, Manufacturing, Design and Manufacture and Asset Management.

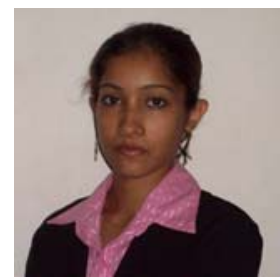

Krystal Ramoutar graduated from the University of the West Indies, St. Augustine in 2007 with a BSc. (Hons) in Industrial Engineering. Currently, she is pursuing her MPhil in Manufacturing Engineering. Her interests are in the following research areas: Manufacturing Performance, World-Class Manufacturing, Health and Safety and Ergonomics. 